\title{
Market economy problems
}

\section{London}

1990 promises to be a testing time for Polish science, thanks to the country's continuing economic problems. The Polish government has already announced that there will be less central funding for research, and it is rumoured that many research institutes will be forced to close. Professor Wojtek Zakrzewski, of the University of Durham, says that Polish physicists with whom he is in contact fear for their survival.

Researchers within the university network may fare better. Andrzej Kowalczyk, of the Nicholas Copernicus University in Torun, believes that universities are protected by public and government perception of their important "social role". Certainly, there are no rumours of drastic cuts in university teaching.

The current crisis of funding for Polish science stems from the Solidarity-led government's moves towards a market economy, needed to secure vital loans from the International Monetary Fund. As part of this plan, the official exchange rate for the zloty was put within the black market range for the first time on 1 January. Although Polish scientists HISTORY OF SCIENCE

\section{Raman memorabilia gathering dust}

\section{New Delhi}

As India celebrates the centenary of the birth of Nobel laureate physicist C. V. Raman, his university, Rajabazar College in Calcutta, has been embarrassed by the revelation that a collection of musical and scientific instruments used by Raman is mouldering in a college classroom. Lack of space and money, the college says, has meant that the historically important instruments have been left unguarded and unprotected.

The story goes that the discovery for which the physicist won the Nobel prize the Raman effect in spectroscopy - was made with equipment worth about 100 rupees (\$6). In later years, Raman devoted his energies to acoustical studies, especially of musical instruments, and acquired a piano and an organ. According to a college spokesman, these instruments, now rusty, were left in an open classroom to provide a source of inspiration to students.

Although these same students are now complaining that the college has been negligent in its upkeep of Raman's memorabilia, the college is resisting efforts to remove them to a museum. But it says that it would like to preserve the items "in a better way" on the college campus, if money and a suitable location can be found.

K. S. Jayaraman should now have a freely convertible currency, the poor exchange rate (about 10,000 zlotys to the US dollar) means that purchase of Western journals and equipment may now become more difficult.

Polish science is also crippled by the bureaucratic organization of the Academy of Sciences which through its network of research institutes sponsors the major part of Poland's basic research. Set up along Soviet lines, the academy has been "top heavy ... . and dominated by the [Communist] party", according to Zbigniew Pelczynski, a fellow of Pembroke College, Oxford, and a regular visitor to Poland.

There have been changes in personnel within the academy, including the election of a new praesidium, but the stultifying structure remains. Professor Andrzej Ziabicki, on the advisory board of the Polish Society for the Advancement and Promotion of Science (TPKN), an acade- mic pressure group closed down during martial law for "anti-socialist activities", thinks the academy cannot continue in its present shape. A more appropriate role would be as honorary body, similar to the Royal Society in Britain, he says.

TPKN has held discussion meetings on the academy's future organization, attended by government ministers, but the timing of any changes remains uncertain. The government is understood to be sympathetic to demands for reform, but the Polish parliament is snowed under with legislation, and science may take low priority.

A similar situation holds for reform of the universities. Professor Aleksander Koj, director of the Jagellonian University in Krakow, says that legislation to increase the autonomy of universities is being prepared. Ideally, this should be in place before April, when elections for university governing bodies take place. But he says it is a "good question" whether parliament will have the time to meet this deadline.

Peter Aldhous

\section{Bigger budgets proposed}

\section{Tokyo}

JAPAN's Science and Technology Agency (STA) has made a bold proposal that the government should double spending on research to one per cent of gross national product (GNP) in its annual white paper (policy document) released at the end of last month. This is the first time the agency has set such an ambitious target. But it remains to be seen if it will be adopted as government policy.

The white paper notes that while industry has built a powerful research and development structure through "aggressive" investment, boosting Japan's outlays for research and development to 2.6 per cent of GNP in 1988, government invest-

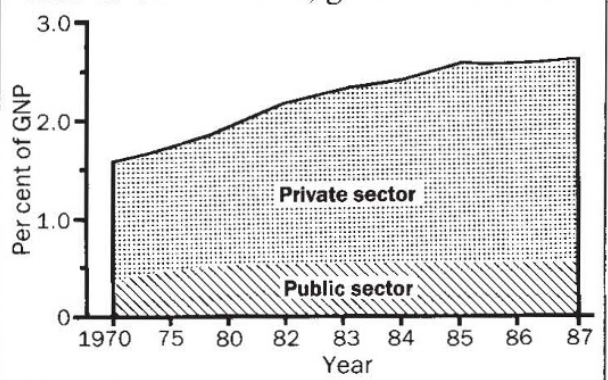

Where the money comes from

ment has remained flat at 0.5 per cent of GNP for the past 20 years.

Industry's investment in basic research has shown particularly rapid growth, going from $¥ 100,000$ million in 1978 to more than $¥ 400,000$ million in 1987 $(\$ 2,900$ million $)$. The white paper says there is a need for the public sector to match this trend.

Yoshiro Miki, director of the policy research division of STA, says that the agency decided to specify the goal of one per cent of GNP at this stage because the Ministry of Finance is beginning to expand the national budget after years of fiscal restraint.

But he says it will probably be "two or three years" before the Council for Science and Technology, Japan's chief science policy-making body, makes a decision on whether to adopt the agency's target.

The white paper also calls on the government to develop research facilities, such as science parks, in local regions. At present, nearly half of Japan's 215,000 corporate researchers are concentrated in the Tokyo area. Miki says that local governments have huge amounts of money which they are eager to spend on science and technology. But they lack facilities and personnel.

The Ministry of International Trade and Industry established the 'technopolis' project in the early 1980 s to develop local regions (see Nature 329, 478; 1987). But Miki says that although the project was "far sighted" it has so far been "a failure", with one or two exceptions. Part of the problem is that, until recently, industry felt it necessary to be in the Tokyo area for reasons of efficiency. But this attitude is changing, Miki says. As an example he points to the agency's plan to establish the world's most powerful synchrotron in Hyogo Prefecture near Osaka (see Nature 336, 613; 1988) the operation of which will be supported by a new company set up with industry funding. David Swinbanks 